\title{
TEKNIK SAMPLING DALAM PENELITIAN
}

\author{
Oleh: Triyono ${ }^{1}$
}

\begin{abstract}
Abstrak
Penerapan rumus-rumus statistik parametrik dalam suatu penelitian menuntut dipenuhinya beberapa persyaratan, akan tetapi hal itu sering tidak dilakukan oleh para peneliti. Jika persyaratan tersebut tidak dipenuhi, tidak ada alasan bagi peneliti untuk membuat generalisasi hasil penelitian ke populasi yang lebih luas, dari mana sampel diambil. Syarat-syarat itu ialah (a) sampel ditarik secara acak, (b) sampel diambil dari populasi yang terdistribusi normal. Apabila salah satu syarat tadi tidak terpenuhi, seharusnya berpaling ke statistik nonparametrik. Tulisan ini membahas bagaimana seharusnya pengambilan sampel dilakukan.
\end{abstract}

Kata kunci: probalility sampling, non-probability sampling, parametrik, non-parametrik

\section{Pendahuluan}

Dalam suatu penelitian survei, tidak perlu untuk meneliti semua individu dalam suatu populasi, sebab di samping memakan biaya yang banyak, juga membutuhkan waktu yang lama. Dengan meneliti sebagian dari populasi, diharapkan hasil yang diperoleh akan dapat menggambarkan sifat populasi yang bersangkutan. Untuk dapat mencapai tujuan ini, maka cara-cara pengambilan sebuah sampel harus memenuhi syarat-syarat tertentu.

Sebuah sampel harus dipilih sedemikian rupa sehingga setiap satuan unsur mempunyai kesempatan dan peluang yang sama untuk dipilih, dan besarnya peluang tersebut tidak boleh sama dengan nol. Di samping itu, pengambilan sampel secara acak (random) harus menggunakan teknik yang tepat sesuai dengan ciri-ciri populasi dan tujuan penelitian.

Menurut Teken (1965) suatu teknik pengambilan sampel yang ideal mempunyai sifat-sifat (1) dapat menghasilkan gambaran yang dapat dipercaya dari seluruh populasi yang diteliti, (2) dapat menentukan presisi (presicion) dari hasil penelitian dengan menentukan simpangan baku (standard deviation) dari taksiran yang diperoleh, (3) sederhana, sehingga mudah dilaksanakan, dan (4)

\footnotetext{
${ }^{1}$ Dosen FKIP Universitas Palangkaraya
} 
dapat memberikan keterangan sebanyak mungkin, dengan biaya yang serendahrendahnya.

Dalam menentukan teknik pengambilan sampel yang akan diterapkan dalam suatu penelitian, seorang peneliti harus memperhatikan hubungan antara biaya, tenaga, dan waktu di satu pihak, serta tingkat presisi di pihak lain. Jika jumlah biaya, tenaga, dan waktu sudah dibatasi sejak semula, seorang peneliti harus berusaha mendapatkan teknik pengambilan sampel yang menghasilkan presisi tertinggi. Perlu disadari bahwa tingkat presisi yang tinggi tidak mungkin dapat dicapai dengan biaya, tenaga, dan waktu yang terbatas. Di samping itu, perlu diperhatikan pula masalah "efisiensi" dalam memilih teknik pengambilan sampel. Menurut Teken (1965: 39), metode A dikatakan lebih efisien daripada metode $B$, jika untuk sejumlah biaya, tenaga, dan waktu yang sama, metode $A$ dapat memberikan tingkat presisi yang lebih tinggi; atau untuk tingkat presisi yang sama diperlukan biaya, tenaga, dan waktu yang lebih rendah.

Sering timbul pertanyaan, berapa besarnya sampel (sample size) yang harus diambil untuk mendapatkan data yang representatif. Ada empat faktor yang harus dipertimbangkan dalam menentukan besarnya sampel dari suatu penelitian, yaitu:

(1) Derajad keseragaman (degree of homogenity) dari populasi. Makin seragam populasi, makin kecil sampel yang bisa diambil. Jika populasi seragam penuh (completely homogenous), maka satu satuan elemen saja sudah cukup representatif untuk diteliti. Sebaliknya, apabila populasi itu secara sempurna tidak seragam (completely heterogeneous), maka hanya pencatatan lengkap yang dapat memberikan gambaran secara representatif.

(2) Presisi yang dikehendaki dari penelitian. Makin tinggi tingkat presisi yang dikehendaki, makin besar jumlah sampel yang harus diambil. Jadi, sampel yang besar cenderung memberikan penduga yang lebih mendekati nilai sesungguhnya (true-value). Pada sensus lengkap, tingkat presisi ini menjadi mutlak, karena nilai taksiran statistik sama dengan nilai parameter. Dengan perkataan lain, antara besarnya sampel yang diambil dengan besarnya kesalahan (error) terdapat hubungan yang negatif. 
(3) Rencana analisis. Adakalanya besarnya sampel sudah mencukupi sesuai dengan tingkat presisi yang dikehendaki, akan tetapi jika dikaitkan dengan kebutuhan analisis, jumlah sampel tersebut kurang mencukupi. Sebagai contoh, jika seorang peneliti ingin menghubungkan tingkat pendidikan responden dengan pemakaian alat kontrasepsi. Jika tingkat pendidikan responden dikelompokkan menjadi $\left(\mathrm{a}_{1}\right)$ belum sekolah, $\left(\mathrm{a}_{2}\right)$ belum tamat $\mathrm{SD}$, $\left(a_{3}\right)$ tamat SD, $\left(a_{4}\right)$ belum tamat $\operatorname{SLTP},\left(a_{5}\right)$ tamat $\operatorname{SLTP},\left(a_{6}\right)$ belum tamat SLTA, $\left(a_{7}\right)$ tamat SLTA, $\left(a_{8}\right)$ pernah kuliah, $\left(a_{9}\right)$ tamat $D-1,\left(a_{10}\right)$ tamat D-2, $\left(a_{11}\right)$ tamat D-3, $\left(a_{12}\right)$ tamat $S-1$; sedangkan jenis alat kontrasepsi dibagi ke dalam $\left(b_{1}\right)$ spriral, $\left(b_{2}\right)$ kondom, $\left(b_{3}\right)$ pil, $\left(b_{4}\right)$ vasektomi; maka dengan sampel 150 responden mungkin tidak cukup, sebab akan terdapat sel-sel dalam matrik yang isinya kurang dari 5 atau bahkan kosong.

(4) Tenaga, waktu, dan biaya. Jika diinginkan tingkat presisi yang tinggi, maka jumlah sampel harus besar. Tetapi jika dana, waktu, dan tenaga yang tersedia sangat terbatas, tidak mungkin untuk mengambil sampel yang besar; dan ini berarti tingkat presisinya akan menurun.

Mengenai ukuran sampel minimum yang harus diambil dari suatu populasi, berikut ini diketengahkan beberapa sumber. Barbara dan Fidell (1983: 91) mengatakan jika rencana analisis yang digunakan berupa teknik korelasi dan regresi ganda, ukuran sampel yang ideal haruslah 20 kali banyaknya variabel bebas. Tetapi Comrey (1973: 76) menyatakan bahwa untuk berbagai tujuan penelitian, jika subjeknya homogen dan banyaknya variabel yang diteliti tidak banyak, ukuran sampel antara 100-200 sudah baik. Cochran (1965: 54) memberikan rumus yang digunakan untuk menentukan besarnya sampel minimum dalam suatu penelitian survei sebagai berikut.

$$
\mathrm{n}=\frac{\frac{\mathrm{t}^{2} \cdot P \cdot Q}{\mathrm{~d}^{2}}}{1+1 / \mathrm{N}\left\{\frac{\mathrm{t}^{2} \cdot P \cdot Q}{\mathrm{~d}^{2}}-1\right\}}
$$




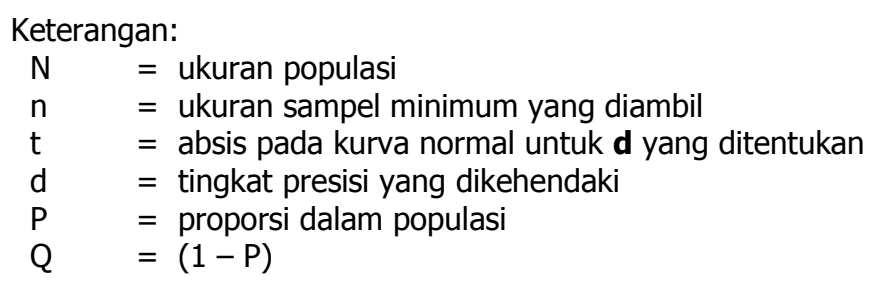

\section{Satuan Sampling}

Sebelum memahas tentang beberapa teknik pengambilan sampel, terlebih dahulu perlu dipahami beberapa konsep sebagai berikut.

\section{Populasi}

Populasi (universe) ialah jumlah keseluruhan dari unit analisis yang ciricirinya akan diduga. Populasi dapat dibedakan antara populasi sampling dengan populasi sasaran. Sebagai contoh, jika seorang peneliti mengambil rumahtangga sebagai sampel; sedangkan yang diteliti hanya anggota rumahtangga (misalnya ayah atau suami), maka seluruh rumahtangga dalam wilayah penelitian disebut sebagai populasi sampling; sedangkan seluruh suami atau ayah dalam wilayah penelitian itu dinamakan populasi sasaran (target population).

Dalam setiap penelitian, populasi yang dipilih erat kaitannya dengan masalah yang akan diteliti. Sebagai contoh, (1) untuk penelitian tentang tenaga kerja, mestinya populasi yang dipilih adalah penduduk usia kerja, (2) untuk penelitian tentang pemilihan umum, mestinya populasi yang dipilih adalah penduduk yang memiliki hak pilih, (3) untuk penelitian tentang fertilitas, populasi yang dipilih adalah penduduk perempuan usia 15-49 tahun yang pernah kawin.

\section{Unit sampling}

Unsur-unsur yang diambil sebagai sampel, disebut unsur sampling, dan ini merupakan unit-unit yang akan dianalisis selanjutnya. Unsur sampling diambil dengan menggunakan kerangka sampling (sampling frame).

\section{Kerangka sampling}

Kerangka sampling merupakan daftar dari semua unsur sampling dalam populasi sampling. Kerangka sampling dapat berupa daftar mengenai jumlah penduduk, jumlah bangunan, dan mungkin berupa peta yang unit-unitnya tergambar secara jelas. Sebuah kerangka sampling yang baik harus memenuhi 
syarat-syarat (1) meliputi seluruh unsur sampel, (2) tidak ada unsur sampel yang dihitung dua kali, (3) up to date, (4) batas-batasnya jelas, misalnya batas wilayah, rumahtangga; dan (5) dapat dilacak di lapangan.

\section{Beberapa Teknik Pengambilan Sampel}

Sebelum pembicaraan lebih lanjut, perlu dijelaskan bahwa pada dasarnya ada dua macam metode pengambilan sampel, yaitu (1) pengambilan sampel secara acak (random sampling) atau probability sampling, dan (2) pengambilan sampel yang bersifat tidak acak (non-probability sampling), dimana sampel dipilih berdasarkan pertimbangan-pertimbangan tertentu.

\section{Sampling Acak Sederhana}

Sampel acak sederhana (simple random sampling) ialah suatu sampel yang diambil sedemikian rupa sehingga tiap unit penelitian dari suatu populasi mempunyai kesempatan yang sama untuk dipiih sebagai sampel. Dalam prakteknya, sampel acak sederhana dapat dilakukan dengan (a) undian, atau (b) bilangan acak.

\section{Sampling Sistematis}

Apabila banyaknya satuan elementer yang akan dipilih cukup besar, maka pemilihan sampel acak sederhana akan berat mengerjakannya. Dalam keadaan seperti ini ahli statistik cenderung memakai metode lain. Pengambilan sampel acak sistematis (systematic random sampling) ialah suatu metode pengambilan sampel, dimana hanya unsur pertama saja dari sampel dipilih secara acak, sedangkan unsur-unsur selanjutnya dipilih secara sistematis menurut pola tertentu. Sampel sistematis seringkali menghasilkan kesalahan sampling (sampling error) yang lebih kecil, disebabkan anggota sampel menyebar secara merata di seluruh propinsi.

Ada pendapat bahwa pengambilan sampel dengan metode ini tidak acak, karena yang diambil secara acak unsur pertama saja, sedangkan unsur selanjutnya diurutkan berdasarkan interval yang sudah tertentu dan tetap. Karena itu, untuk dapat mempergunakan metode ini, harus dipenuhi beberapa syarat yakni (1) populasi harus besar, (2) harus teredia daftar kerangka sampel, (3). populasi harus bersifat homogen. 


\section{Sampling Acak Berlapis}

Dalam praktek sering dijumpai populasi yang tidak homogen. Makin heterogen suatu populasi, makin besar pula perbedaan sifat antara lapisanlapisan tersebut. Presisi dan hasil yang dapat dicapai dengan penggunaan suatu metode pengambilan sampel, antara lain dipengaruhi oleh derajat keseragaman dari populasi yang bersangkutan.

Untuk dapat menggambarkan secara tepat mengenai sifat-sifat populasi yang heterogen, maka populasi yang bersangkutan dibagi ke dalam lapisanlapisan (stratum) yang seragam dan dari setiap lapisan diambil sampel secara acak. Dalam sampel berlapis, peluang untuk terpilih satu strata dengan yang lain mungkin sama, mungkin pula berbeda.

Ada dua syarat yag harus terpenuhi untuk dapat mempergunakan metode pengambilan sampel acak berlapis, yaitu (a) ada kriteria jelas yang akan dipergunakan sebagai dasar untuk menstratifikasi populasi, dan (b) diketahui dengan tepat jumlah satuan-satuan elementer dari tiap lapisan dalam populasi itu. Besarnya sampel yang diambil dari tiap-tiap strata dapat berimbang dan dapat pula tidak berimbang. Dalam pengambilan sampel yang berimbang, unsur-unsur satuan yang diambil dari setiap strata berbanding lurus dengan jumlah satuan-satuan elementer dalam strata yang bersangkutan. Kalau peneliti akan mempergunakan metode tidak berimbang, maka ia dapat menentukan sendiri jumlah unsur-unsur sampel yang akan diambilnya.

\section{Samping Gugus (Cluster) Sederhana}

Jika seorang peneliti ingin meneliti besarnya pendapatan per bulan dari tiap-tiap keluarga di suatu kecamatan, sedangkan data mengenai jumlah keluarga di kecamatan tersebut tidak tersedia, maka kecamatan tersebut dibagi menjadi desa-desa. Desa-desa itu dijadikan gugus atau unsur sampling. Semua desa yang ada diberi nomor dan dipilih secara acak sebuah desa atau lebih sebagai sampel. Karena unsur penelitian adalah keluarga atau rumahtangga, maka semua rumahtangga yang ada dalam desa tersebut yang diteliti. 


\section{Sampling Wilayah}

Adakalanya peneliti dihadapkan pada wilayah penelitian dengan berbagai ciri khusus pada beberapa bagian wilayah tersebut. Dalam keadaan seperti itu, sampling wilayah (area) mungkin akan lebih tepat digunakan. Sebagai contoh, Mubyarto (1993) membedakan empat macam pola usahatani di Kalimantan Tengah yaitu (a) pola usahatani perladangan berpindah, yang terdapat di kecamatan-kecamatn Gunung Purei, Tanah Siang, dan Balai Riam, (b) pola usahatani perikanan, khususnya darat yang dijumpai di hampir semua desa di tepian sungai, (c) pola usahatani tanaman pangan pasang surut, yang terdapat di kecamatan Kahayan Kuala, dan Kahayan Hilir, serta (d) poloa usahatani perkebunan yang terdapat di kecamatan Kumai. Masyarakat dari keempat wilayah dengan pola usahatani yang berbeda itu akan memiliki ciri-ciri khusus yang menarik untuk diungkap.

Jika penarikan sampel dalam suatu penelitian tidka dilakukan dengan prinsip probabilitas, hasil penelitiannya tidak seharusnya digeneralisasikan ke populasi yang lebih luas. Porpusive sampling dan i samping, merupakan dua contoh teknik pengambilan sampel yang tidak menggunakan prinsip probability sampling.

\section{Daftar Pustaka}

Barbara, G.T. dan Fidell L.S. (1983). Using Multivariate Statistics. New York: Harper \& Row Publishers.

Cochran, W.G. (1965). Sampling Techniques. New York: John Wiley \& Sons, Inc.

Comrey, A.L. (1973). First Cource in Factor Analysis. New York: Academic Press.

Singarimbun, M. dan Effendi, S. (Eds). Metode Penelitian Survei. Jakarta: LP3ES.

Mubyarto, et al. (1993). Desa-desa Kalimantan. Studi Bina Desa Pedalaman Kalimantan Tengah. Yogyakarta: Aditya Media. 